\begin{tabular}{|l|l|l|}
\hline \multicolumn{2}{|c|}{ PublisherInfo } \\
\hline \hline PublisherName & $:$ & BioMed Central \\
\hline \hline PublisherLocation & $:$ & London \\
\hline \hline PublisherImprintName & $:$ & BioMed Central \\
\hline \hline
\end{tabular}

\title{
Effects of hyper-resorptive osteoclasts on SHIP-deficient mice
}

\begin{tabular}{|l|l|l||}
\hline \multicolumn{2}{|c|}{ ArticleInfo } \\
\hline \hline ArticleID & $:$ & 251 \\
\hline \hline ArticleDOI & $:$ & $10.1186 /$ ar-2002-78153 \\
\hline \hline ArticleCitationID & $:$ & 78153 \\
\hline \hline ArticleSequenceNumber & $:$ & 4 \\
\hline \hline ArticleCategory & $:$ & Paper Report \\
\hline \hline ArticleFirstPage & $:$ & 1 \\
\hline \hline ArticleLastPage & $:$ & 4 \\
\hline \hline & & RegistrationDate $: 2002-9-26$ \\
ArticleHistory & $:$ & Received \\
& Accepted 2002-9-26 & $: 2002-11-19$ \\
& $: \mid$ & OnlineDate $\quad: 2002-11-19$ \\
\hline \hline ArticleCopyright & $:$ & Biomed Central Ltd2002 \\
\hline \hline ArticleGrants & $:$ & \\
\hline \hline
\end{tabular}




\begin{tabular}{|l|l|l|}
\hline ArticleContext & $:$ & 130754411 \\
\hline
\end{tabular}

Jason M Weaver, ${ }^{\text {Aff1 }}$

Aff1 University of Rochester, NY, USA

\section{Keywords}

Osteoclast, osteoporosis, Paget Disease, SHIP

\section{Context}

Mature osteoclasts are specialized macrophage polykaryons formed by the fusion of mononuclear progenitors of the monocyte/macrophage lineage. They function as the primary resorptive cell of bone and modulate the formation of the skeleton and regulation of its mass. The rate of bone degradation is dependent upon the osteoclast number and the bone-resorptive capacity upon the mature osteoclast. Osteoclast precursor survival and differentiation is dependent on the signaling of macrophage colonystimulating factor (M-CSF) and receptor activator of nuclear factor kappa B ligand (RANKL). The intracellular signaling that activates these potent cytokines has not been fully elucidated, but includes phosphatidylinositol 3-kinase (PI3-K) activity. Phosphatidylinositol-3,4,5-triphosphate (PIP3), a major product of PI3-K activity, is specifically recognized and cleaved at a 5'-phosphate group by the Src homology (SH) 2-containing inositol-5-phosphatase (SHIP) protein. The dephosphorylation of PIP-3 by SHIP implicates the proteins' ability to affect the function and signaling of osteoclasts. Here the group assesses and fully characterizes the bone phenotype and osteoclastogenic regulations of a SHIP -/mouse.

\section{Significant findings}

The mineral apposition and bone formation rates were acquired on calvariae and shown to be not significantly different indicating that the SHIP -/- has accelerated bone resorption reflecting the osteoporotic phenotype. SHIP is a negative regulator of osteoclastogenesis and the absence of SHIP increases the sensitivity of M-CSF-dependent bone-marrow macrophages to essential osteoclastogenic cytokines M-CSF and RANKL, resulting in increased osteoclast number, size, nuclei and decreased apoptosis. The increases are synonymous with pathology found in Paget's Disease patients who display enlarged and deformed bones. Preosteoclasts cultured on bone wafers resorbed more bone and formed deeper pits, with an approximately 60 -fold increase in IL-6 levels, implicating IL-6 in regulating 
resorptive activity of osteoclasts and as a potential mediator of osteoclast function in Paget's Disease. Functional relevance of the increased osteoclast number in long bone was assessed by femoral architectural and metaphyseal morphology and biomechanical parameters. The areal bone-mineral density was diminished and the femoral diaphyseal bone stiffness/strength decreased due to reduced cross-sectional size rather than to a defect in material.

\section{Comments}

This group completely characterizes the bone morphological and pathological effects of knocking out the SHIP gene and demonstrates a negative regulatory role in osteoclast formation and function. The group also effectively correlates data to establish a potential mouse model for mimicking pathology observed in Paget's Disease. Since SHIP is clearly noted as a major player in the signaling pathway of osteoclast regulation, finer details of the macrophage-derived preosteoclast pathway and other functional roles of SHIP could be determined using this model system. Thus, it should warrant study of preosteoclast markers, such as c-kit, c-Fms, Fra-1 and CD11b, to determine if there are frequency changes in the gene regulation and expression of potential preosteoclastogenic population of macrophages due to the SHIP gene [see Additional information 1,2].

\section{Methods}

Gene targeting, microcomputed tomography scanning, dual energy x-ray absorptiometry, histomorphometry, resorption pit assay

\section{Additional information}

1. Shalhoub V, Elliott G, Chiu L, Manoukian R, Kelley M, Hawkins N, Davy E, Shimamoto G, Beck J, Kaufman SA, Van G, Scully S, Qi M, Grisanti M, Dunstan D, Boyle WJ, Lacey DL:

Characterization of osteoclast precursors in human blood. Br J Haematol. 2000, 111:501-512.

2. Arai F, Miyamoto T, Ohneda O, Inada T, Sudo T, Brasel K, Miyata T, Anderson DM, Suda T: Commitment and Differentiation of Osteoclast Precursor Cells by the Sequential Expression of c-Fms and Receptor Activator of Nuclear Factor kB (RANK) Receptors. J Exp Med. 1999, 190:1741-1754. 


\section{References}

1. Takeshita S, Namba N, Zhao JJ, Jiang Y, Genant HK, Silva MJ, Brodt MD, Helgason CD, Kalesnikoff J, Rauh MJ, Humphries RK, Krystal G, Teitelbaum SL, Ross FP: SHIP-deficient mice are severely osteoporotic due to increased numbers of hyper-resorptive osteoclasts . Nature Med . 2002, 8: 943-949.

This PDF file was created after publication. 